\title{
Asbestos lung burden and asbestosis after occupational and environmental exposure in an asbestos cement manufacturing area: a necropsy study
}

Corrado Magnani, Franco Mollo, Luigi Paoletti, Donata Bellis, Paolo Bernardi, Piergiacomo Betta, Mario Botta, Mario Falchi, Cristiana Ivaldi, Mansueto Pavesi

Servizio Universitario di Epidemiologia dei Tumori, Centre for Cancer Epidemiology and Prevention (CPO-Piemonte), San Giovanni Hospital and University, Torino, Italy

C Magnani

C Ivaldi

$I^{\circ}$ Servizio

Universitario di

Anatomia Patologica, 1st Pathology Unit, San Giovanni Hospital and University, Torino, Italy

F Mollo

D Bellis

P Bernardi

Laboratorio di Ultrastrutture, Istituto Superiore di Sanità, Roma, Italy L Paoletti M Falchi

Reparto di Oncologia, Oncology Unit, General Hospital, Casale Monferrato, Italy

M Botta

Servizio di Anatomia Patologica - Pathology Unit - General

Hospital -Casale Monferrato, Italy

P Betta

M Pavesi

Correspondence to: Dr C Magnani, Servizio di Epidemiologia dei Tumori, Via Santena 7, 10126 Torino, Italy.

Accepted 16 July 1998

\begin{abstract}
Objective-The largest Italian asbestos cement factory had been active in Casale Monferrato until 1986: in previous studies a substantial increase in the incidence of pleural mesothelioma was found among residents without occupational exposure to asbestos. To estimate exposure to asbestos in the population, this study evaluated the presence of histological asbestosis and the lung burden of asbestos fibres (AFs) and asbestos bodies (ABs).
\end{abstract}

Methods-The study comprises the consecutive series of necropsies performed at the Hospital of Casale Monferrato between 1985 and 1988. A sample of lung parenchima was collected and stored for 48 out of 55 necropsies. The AF concentration was measured with a TEM electron microscope with $x$ ray mineralogical analysis. The ABs were counted and fibrosis evaluated by optical microscopy. The nearest relative of each subject was interviewed on occupational and residential history. Mineralogical and histological analyses and interviews were conducted in 1993-4.

Results-Statistical analyses included 41 subjects with $A F, A B$ count, and interview. Subjects without occupational exposure who ever lived in Casale Monferrato had an average concentration of $1500 \mathrm{AB} / \mathrm{g}$ dried weight (gdw); Seven of 18 presented with asbestosis or small airway lung disease (SAL). G2 asbestosis was diagnosed in two women with no occupational asbestos exposure. One of them had been teaching at a school close to the factory for 12 years. Ten subjects had experienced occupational asbestos exposure, seven in asbestos cement production: mean concentrations were $1.032 \times 10^{6} \mathrm{AF} / \mathrm{gdw}$ and $96280 \mathrm{AB} / \mathrm{gdw}$. Eight of the $10 \mathrm{had}$ asbestosis or SAL.

Conclusion-The high concentration of ABs and the new finding of environmental asbestosis confirm that high asbestos concentration was common in the proximity of the factory. Subjects not occupationally exposed and ever living in Casale Monferrato tended to have higher $A B$ concentration than subjects never living in the town (difference not significant). The concentrations of $\mathrm{ABs}$ and $\mathrm{AFs}$ were higher than those found in other studies on nonoccupationally exposed subjects. (Occup Environ Med 1998;55:840-846)

Keywords: lung burden; asbestosis; asbestos cement manufacture

The largest Italian asbestos cement factory operated in the town of Casale Monferrato (north west Italy) from 1907 to 1986 . Since 1987, epidemiological studies have measured the effects of occupational, domestic, and environmental asbestos exposure, and found an increase in mortality from respiratory cancer and incidence of mesothelioma among asbestos cement workers ${ }^{1}$ and in incidence of mesothelioma among their wives ${ }^{23}$ and in the general population without occupational exposure. $^{3}$

The factory employed up to 1500 workers, produced various asbestos cement products including high pressure pipes, and used both crocidolite and chrysotile. ${ }^{1}$ In 1981 the company reported the use of 15000 metric tonnes of asbestos, $10 \%$ of which was crocidolite. Environmental asbestos pollution in Casale Monferrato also originated from the large use of asbestos cement products: the Town Office estimated in 1990 that asbestos cement roofs amounted to $500000 \mathrm{~m}^{2}$ in a town of about 40000 inhabitants. The factory is about 1300 $\mathrm{m}$ from the centre of the town and $250 \mathrm{~m}$ from the closest residential areas. The town is downwind from the factory in respect to dominant winds. ${ }^{4}$

Measures of environmental asbestos exposure in the town of Casale Monferrato are limited in number and close in time, or subsequent to the cessation of asbestos cement production. Marconi et al in 1984 reported average concentrations of asbestos fibres (AFs) longer than $5 \mu \mathrm{m}$ of $11 \mathrm{AF} / 1$ close to the plant and $1 \mathrm{AF} / 1$ in the city area farthest away from it. ${ }^{4} \mathrm{~A}$ study conducted between March 1990 and July 1991 by the Local Health Authority in cooperation with the ISS measured in 12 sampling sites in the town annual averages below $1 \mathrm{AF} / 1$ (longer than $5 \mu \mathrm{m}$ ). This threshold was exceeded in $12 \%$ of samples (Internal report, Local Health Authority of Casale Monferrato). Chiappino et al in 1991 found that the average concentration of $\mathrm{AF}$ (length $>5 \mu \mathrm{m}$ and diameter $>0.3 \mu \mathrm{m}$ ) was in the range $2.2-7.4 \mathrm{AF} / 1$ in residential areas of the city. ${ }^{5}$ In these studies the 


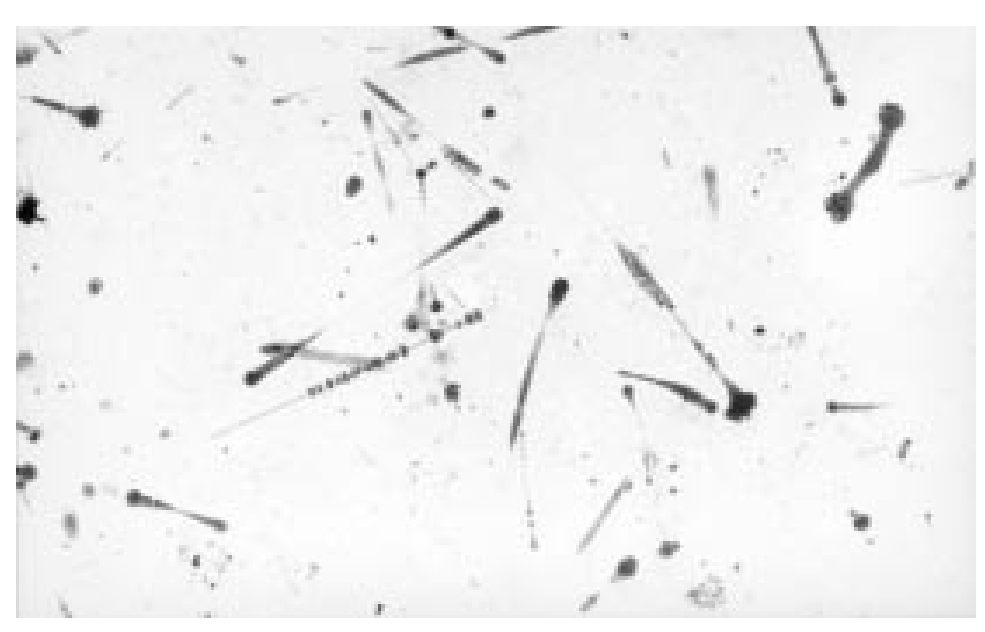

Figure 1 Microphotograph of a preparation used for counting asbestos bodies.

proportion of amphiboles ranged between $15 \%$ and $50 \%$ of AFs. The results of those studies are difficult to compare because of the different sampling and analytical methods; nevertheless, they suggest that the concentration of fibres was higher and the proportion of amphiboles was larger in Casale Monferrato than in the centre of other Italian cities. ${ }^{67}$

No information has been presented so far on the concentration of asbestos fibres and asbestos bodies in the lung and on the prevalence of pulmonary asbestosis among persons living in Casale. Thus, we carried out a preliminary study on a set of samples of lung tissue from the necropsies performed in $1985-8$ at the local hospital. On those samples we evaluated the presence of lung asbestosis and small airway lesions (SAL) and measured the concentration of AFs and asbestos bodies (ABs). These variables were related to indicators of occupational and residential asbestos exposure.

\section{Materials and methods}

The present study comprises the consecutive (unselected) series of necropsies performed at the General Hospital of Casale Monferrato between July 1985 and July 1988.

Out of 55 necropsies in the period, a sample of a lung parenchyma was available for 48 . The remaining seven necropsies were conducted before December 1986 when only one of the pathologists in the hospital participated in the collection of lung samples. Necropsies were requested by the attending clinician for the elucidation of clinical questions and were not selected on exposure to asbestos. Age and sex distribution of subjects was similar to that of decedents in the hospital.

A sample of lung parenchyma was routinely collected for each necropsy, formaldehyde fixed, identified with a progressive number, and stored. Tissue collection was not optimal as only one sample was available for each person and the location had not been recorded. Each sample was then divided into two parts, which were sent respectively to the "Laboratorio di Ultrastrutture" of ISS for the identification of fibres and to the Unit of Pathology (headed by FM) of the S Giovanni Hospital for diagnosis of fibrosis and $\mathrm{AB}$ count.
A personal interview took place in 1994 with the nearest relative of subjects in the study to obtain information on: smoking habits, occupational history, residential history, and chest diseases. Occupational exposure in the asbestos cement industry was defined on the basis of both the interview and the nominal search in the rosters of the employees in the local asbestos cement industry. ${ }^{3}$ Occupational asbestos exposure in other activities was estimated on the basis of interview data. Among the occupations held by study subjects, those considered at definite or probable exposure were in the asbestos cement production (any job) and in the construction industry. No other asbestos related jobs were found in the study.

Both the interviews and the microscopical analyses were done blindly.

Forty one people were included in the statistical analyses. The remaining six were excluded either because the interview could not be carried out (five instances) or the sample was inadequate for fibre counting on the electron microscope (one instance). An outlyer was also excluded. He was a farmer who lived in a rural village close to Casale Monferrato and had two sons working in asbestos cement production from 1960 to 1986; no occupational asbestos exposure was reported, with the possible exception of the construction of some warehouses with asbestos cement roofs in the farm courtyard; his lung burden measured 532000 fibres/gdw (dry weight) of crocidolite and 770 $\mathrm{ABs} / \mathrm{gdw}$. He presented histological signs of SAL and died from pleural mesothelioma.

\section{FIBROSIS AND ASBESTOS BODIES}

Histological examinations and $\mathrm{AB}$ counts were performed by light microscopy. The ABs were measured using about $100 \mathrm{mg}$ (dehydrated tissue) of lung parenchyma without pleura or bronchi: the concentration $(\mathrm{AB} / \mathrm{gdw})$ was determined by optical count after membrane filtration of the material that was obtained by hypochlorite digestion. ${ }^{8-10}$ Figure 1 shows a microphotograph of a preparation used to count ABs. A fragment of about $5 \mathrm{ml}$ lung parenchyma was fixed and used for histological examination. Several slides (four to six usually, from one or more paraffin embedded blocks) were considered for the definition of asbestosis and SAL. Features of asbestosis were searched for on sections stained with haematoxylineosin and graded according to Craighead et $a l .{ }^{11}$ SAL was defined according to Wright and Churg $^{12}$ as pathological changes characterised by fibrosis with possible pigmentation of respiratory bronchioles with or without fibrosis of alveolar ducts. The diagnosis of SAL implies that $\mathrm{ABs}$ were not found on the examined sections, as the association of SAL and $\mathrm{ABs}$ is classified as grade 1 asbestosis. ${ }^{13}$

\section{FIBRE COUNT AND MINERALOGICAL ANALYSES}

Parenchyma samples, 40 to $200 \mathrm{mg}$ of dehydrated tissue depending on the size of the original lung sample, were digested using hydrogen peroxide and sodium hypochlorite. The solution was filtered on cellulose ester filters (pore size $0.45 \mu \mathrm{m}$ ). The filters were dried, 
Table 1 Descriptive information on the necropsy cases in the hospital at Casale Monferrato (1985-8) included in the present analyses

\begin{tabular}{lrr}
\hline Variable & $n$ & $\%$ \\
\hline Sex: & 18 & 43.9 \\
$\quad$ Men & 23 & 56.1 \\
Women & 2 & 4.9 \\
Age: & 12 & 29.3 \\
$\leqslant 49$ & 27 & 65.9 \\
$50-69$ & & \\
$\geqslant 70$ & 24 & 58.3 \\
Residence: & 4 & 9.8 \\
Casale & 8 & 19.5 \\
Surrounding villages & 5 & 12.2 \\
Rest of the local health authority & & \\
Other & 13 & 31.7 \\
Birthplace: & 3 & 7.3 \\
Casale & 8 & 19.5 \\
Surrounding villages & 17 & 41.5 \\
Rest of the local health authority & & \\
Other & 4 & 9.8 \\
Cause of death: & 4 & 17.1 \\
Mesothelioma & 16 & 39.0 \\
Lung cancer & 10 & 24.4 \\
Other malignancies & 3 & 7.3 \\
Cardiovasvular diseases & 1 & 2.4 \\
Respiratory diseases & & \\
Other diseases &
\end{tabular}

${ }^{\star}$ One death from asbestosis.

covered with a thin carbon film, cut, and mounted on standard 200 mesh copper grids for transmission electron microscopy (TEM) and then exposed to acetone fumes to dissolve the filters. ${ }^{14}$

All the reagents and the solutions used in the sample preparation were filtered through Millex-GS $0.22 \mu \mathrm{m}$ pore size sterile filters (Millipore), to avoid particulate contamination. Two blank samples were prepared in different phases of the study by filtering $50 \mathrm{ml}$ sterile saline solution through $0.45 \mu \mathrm{m}$ pore size cellulose nitrate filter. No significant contamination was found at EM analyses.

The mineral particulate on carbon films was analysed by a TEM Philips EM430 equipped with an EDAX energy dispersive spectrometer for $x$ ray microanalysis. Accelerating voltage was $250 \mathrm{KeV}$ and magnification was $10000 \times$. For each subject, 25 to 40 grid apertures (an aperture effective area being about $8400 \mu \mathrm{m}^{2}$ ) in at least five different grids were examined.

The fibres and the mineral particles detected were identified by morphology, chemical composition (elements with atomic number $>11$ ), and crystalline structure. All fibres, independent of length, and all mineral particles were counted. ${ }^{15}$ Fibre and particle concentration is reported in $10^{6} / \mathrm{gdw}$.

\section{STATISTICAL ANALYSES}

Data on fibre and $\mathrm{AB}$ concentrations are summarised by the arithmetic mean (SD). As only one necroscopy sample was available for every subject it was impossible to perform repeated analyses of fibre burden.

Fibre concentration was compared over classes of exposure using Kruskall-Wallis or Mann-Whitney non-parametric tests. ${ }^{16}$ Subjects with no fibres or no ABs detected were included with the value of 0 . This underestimates the value of the mean compared with the use of a fraction of the detection limit but does not affect the median and the statistical significance of the tests, which are based on ranks.
Table 2 Necropsy cases in the hospital at Casale Monferrato (1985-8)

\begin{tabular}{|c|c|c|}
\hline & \multicolumn{2}{|c|}{$\begin{array}{l}\text { Occupational } \\
\text { exposure to asbestos }\end{array}$} \\
\hline & Yes & No \\
\hline Subjects $(\mathrm{n})$ & 10 & 31 \\
\hline \multicolumn{3}{|c|}{ Asbestos fibres (total) $\left(10^{6} \mathrm{fibres} / \mathrm{gdw}\right)$ : } \\
\hline 0 & 3 & 17 \\
\hline$<0.5$ & 2 & 14 \\
\hline $0.5-<1$ & 2 & 0 \\
\hline$\geqslant 1$ & 3 & 0 \\
\hline Arithmetic mean & 1.032 & 0.024 \\
\hline $\mathrm{SD}$ & 1.222 & 0.032 \\
\hline Median & 0.563 & 0.0 \\
\hline \multicolumn{3}{|c|}{ Chrysotile $\left(10^{6}\right.$ fibres $\left./ \mathrm{gdw}\right)$ : } \\
\hline 0 & 10 & 26 \\
\hline $0.5-<1$ & 0 & 5 \\
\hline Arithmetic mean & 0.0 & 0.005 \\
\hline SD & 0.0 & 0.012 \\
\hline \multicolumn{3}{|c|}{ Crocidolite $\left(10^{6}\right.$ fibres $\left./ \mathrm{gdw}\right)$ : } \\
\hline 0 & 5 & 24 \\
\hline$<0.5$ & 1 & 7 \\
\hline $0.5-<1$ & 2 & 0 \\
\hline$\geqslant 1$ & 2 & 0 \\
\hline Arithmetic mean & 0.706 & 0.010 \\
\hline SD & 1.107 & 0.021 \\
\hline Median & 0.077 & 0.0 \\
\hline \multicolumn{3}{|c|}{ Tremolite $\left(10^{6}\right.$ fibres/gdw): } \\
\hline 0 & 9 & 27 \\
\hline$<0.5$ & 1 & 4 \\
\hline Arithmetic mean & 0.045 & 0.006 \\
\hline SD & 0.142 & 0.016 \\
\hline \multicolumn{3}{|c|}{ Amphiboles (nos) $\left(10^{6}\right.$ fibres/gdw): } \\
\hline 0 & 8 & 28 \\
\hline$<0.5$ & 1 & 3 \\
\hline $0.5-<1$ & 0 & 0 \\
\hline$\geqslant 1$ & 1 & 0 \\
\hline Arithmetic mean & 0.281 & 0.004 \\
\hline SD & 0.885 & 0.012 \\
\hline Fibrosis absent & 2 & 19 \\
\hline G1 asbestosis & 0 & 0 \\
\hline G2 asbestosis & 2 & 2 \\
\hline G3 asbestosis & 2 & 0 \\
\hline G4 asbestosis & 3 & 0 \\
\hline SAL & 1 & 9 \\
\hline Other & 0 & 1 \\
\hline \multicolumn{3}{|c|}{ Asbestos bodies (light microscope)( $\mathrm{AB} / \mathrm{gdw})$ : } \\
\hline 0 & 2 & 6 \\
\hline$<500$ & 0 & 12 \\
\hline $500-1000$ & 0 & 7 \\
\hline$>1000$ & 8 & 6 \\
\hline Arithmetic mean & 96285 & 1064 \\
\hline SD & 117662 & 1797 \\
\hline Median & 45523 & 321 \\
\hline
\end{tabular}

Median is not reported when 0 in both groups. nos $=$ Not elsewhere specified.

Frequency distributions were compared using the $\chi^{2}$ test.

\section{Results}

Study subjects are described in table 1 . Average age was 71 (SD 13.3) years (range 24-92). Seven subjects $(17.1 \%)$ worked in asbestos cement production and six others (14.6\%) lived with a relative or the spouse working in the asbestos cement industry.

Table 2 presents the concentration of AFs, dust, and $\mathrm{ABs}$ and frequency of asbestosis and SAL in the 41 subjects included in the statistical analyses, according to occupational asbestos exposure. Ten subjects reported occupational asbestos exposure (seven in the asbestos cement industry). The difference between the two groups (defined as "exposed" and "nonexposed') was significant for AFs $(p<0.005)$, crocidolite $(p=0.02)$, and $\mathrm{ABs}(\mathrm{p}=0.006)$ as well as for the frequency of asbestosis and SAL $(p<0.005)$. Correlation between ABs and fibres was poor (ABs and total AFs: Spearman $r=0.28$ among all subjects and -0.01 among 


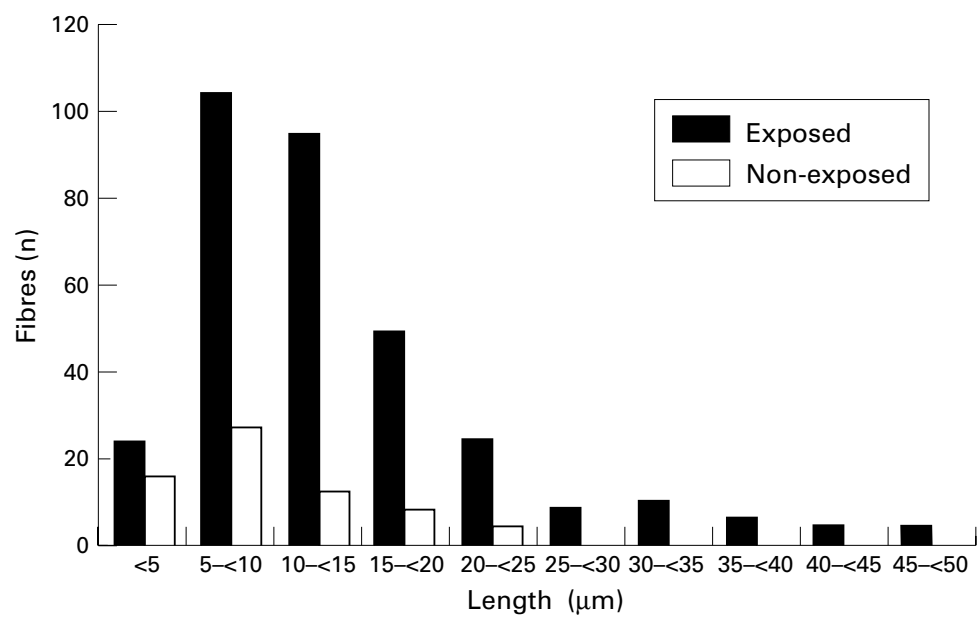

Figure 2 Frequency distribution of amphibole fibre length, according to occupational exposure.

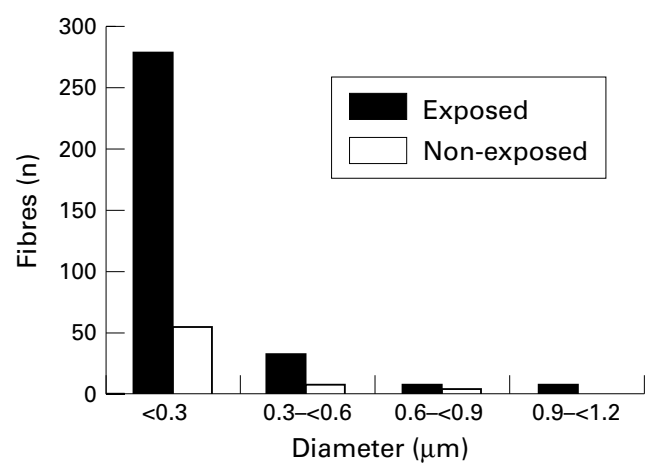

Figure 3 Frequency distribution of amphibole fibre diameter, according to occupational exposure.

reported in most studies ${ }^{17}{ }^{18}$ on workers with exposure to mixed fibre types.

Figures 2 and 3 present the frequency distribution of amphibole fibre length (average 13.6 $\mu \mathrm{m}$ ) and diameters (average $3.6 \mu \mathrm{m}$ ) separately in "exposed" and "non-exposed" groups. Eighty three per cent of fibres were in subjects with occupational asbestos exposure, who also had a higher proportion of long AFs. The average fibre length in subjects with occupational exposure was 16.3 whereas in subjects without occupational exposure it was $11.7(\mathrm{p}<0.0001)$. Diametre distribution was similar in the two groups (mean 0.36 and 0.40). The few chrysotile fibres showed an average length of $11.5 \mu \mathrm{m}$ and an average diameter of $0.8 \mu \mathrm{m}$.

Table 4 presents the concentration of ABs among the 31 subjects with no occupational asbestos exposure, subdivided according to sex and residence (ever in life and irrespective of duration) in Casale Monferrato. In both sexes people who ever lived in Casale presented a higher $\mathrm{AB}$ count but the difference was not significant. Five subjects living in Casale and never resident elsewhere presented more than $1000 \mathrm{ABs}$, whereas AFs did not show remarkable differences according to residence.

Analyses of $\mathrm{AB}$ and $\mathrm{AF}$ concentrations after subdividing Casale Monferrato into smaller units and according to the distance of dwelling from the factory did not provide consistent results because of small numbers and are not presented.

Out of 18 subjects ever living in Casale Monferrato five had SAL and 2 G2-asbestosis, compared with four with SAL and none with asbestosis in the 13 subjects never living there. Both cases of asbestosis were women not occupationally exposed and never living with persons occupationally exposed (fig 4). Both had been in Casale Monferrato for over 50

Table 3 Mean (SD) necropsy cases in the hospital at Casale Monferrato (1985-8)

\begin{tabular}{|c|c|c|c|c|c|c|}
\hline & \multicolumn{3}{|l|}{ No lung fibrosis } & \multicolumn{3}{|c|}{ G1-G4 asbestosis $+S A L$} \\
\hline & \multicolumn{3}{|c|}{ Occupational exposure to asbestos } & \multicolumn{3}{|c|}{ Occupational exposure to asbestos } \\
\hline & Yes & No & $p$ Value & $\overline{Y e s}$ & No & $\overline{p \text { Value }}$ \\
\hline $\mathrm{n}$ & 2 & 20 & & 8 & 11 & \\
\hline Total asbestos fibres $\left(10^{6}\right.$ fibres/gdw $)$ & $1.007(1.424)$ & $0.023(0.034)$ & NS & $1.039(1.277)$ & $0.026(0.029)$ & 0.025 \\
\hline Chrysotile (million fibres/gdw) & $0(0)$ & $0.05(0.012)$ & NS & $0(0)$ & $0.006(0.014)$ & NS \\
\hline Total amphiboles $\left(10^{6}\right.$ fibres/gdw) & $1.007(1.424)$ & $0.019(0.032)$ & NS & $1.039(1.277)$ & $0.020(0.023)$ & 0.024 \\
\hline Asbestos bodies (AB/gdw) & $0(0)$ & $0.461(0.607)$ & NS & $120.356(120.362)$ & $2.152(2.633)$ & 0.003 \\
\hline
\end{tabular}


Table 4 Concentration of $A B$ s according to sex and residence in Casale Monferrato among subjects with no occupational exposure to asbestos

\begin{tabular}{|c|c|c|c|c|c|c|c|}
\hline & \multicolumn{7}{|c|}{ Residents in Casale Monferrato } \\
\hline & \multicolumn{3}{|c|}{ Ever } & \multicolumn{3}{|c|}{ Never } & \multirow{3}{*}{$\begin{array}{l}\text { p Value } \\
\text { (ever v never) }\end{array}$} \\
\hline & \multirow[b]{2}{*}{$n$} & \multicolumn{2}{|c|}{$A B / g d w$} & \multirow[b]{2}{*}{$n$} & \multicolumn{2}{|c|}{$A B / g d w$} & \\
\hline & & mean & $S D$ & & mean & $S D$ & \\
\hline Men & 5 & 3091 & 2620 & 4 & 772 & 931 & NS \\
\hline \multirow[t]{2}{*}{ Women } & 13 & 841 & 1822 & 9 & 379 & 346 & NS \\
\hline & 18 & 1466 & 2244 & 13 & 500 & 576 & NS \\
\hline $\mathrm{p}$ Value (men $v$ women) & \multicolumn{3}{|c|}{0.028} & \multicolumn{3}{|c|}{ NS } & \\
\hline
\end{tabular}

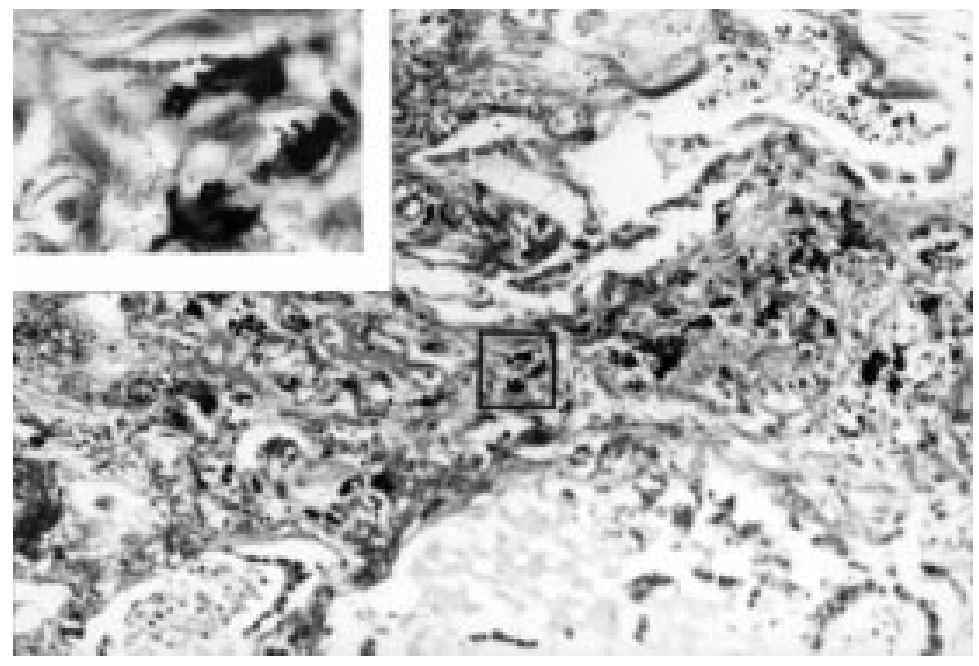

Figure 4 Microphotograph of asbestosis in a woman not occupationally exposed.

years; one was a school teacher who had been working for 12 years (1958-69) in a school close $(250 \mathrm{~m})$ to the asbestos cement factory; no information was available for the other. Both presented $800 \mathrm{AB} / \mathrm{gdw}$.

Seven subjects died from lung cancer and five from mesothelioma. The mean AF concentration for cases of lung cancer was 0.50 (SD $1.25) \times 10^{6}$ fibres $/ g d w$, the mean concentration of crocidolite was 0.49 (SD 1.21$) \times 10^{6}$ fibres/ $\mathrm{gdw}$ and, the mean concentration of $\mathrm{ABs}$ was 44.3 (SD 78.2)/gdw. Corresponding figures for mesothelioma cases were: 0.15 (SD $0.26)$ fibres/gdw for total AFs, 0.13 (SD $0.27) \times 10^{6}$ fibres/gdw for crocidolite and 0.41 (SD 0.26$) / g d w$ for ABs. In cases of mesothelioma only amphibole fibres were detected. Two cases of lung cancer and one of mesothelioma had worked in asbestos cement production. The last had $2.8 \times 10^{6}$ fibres (only amphiboles) and 268800 asbestos bodies. The lung fibre burdens in asbestosis cases were consistently greater than $10^{6}$ fibres/gdw with a mean concentration of $2.4 \times 10^{6}$ fibres/gdw.

\section{Discussion}

The present study, albeit based on limited numbers, is unique as it includes the consecutive series of necropsies conducted in Casale Monferrato in the years immediately after the cessation of asbestos cement production. It is based on samples collected routinely for the archive of the pathology department and analysed separately. The use of these samples is a weakness as the collection was not optimal (only one sample a subject, taken from an unspecified part of the lung): the effect could be a reduction of the fibre count in some subjects and an increased variability. By contrast, the interval between tissue collection and the analyses does not affect the results as AFs are stable in formaldehyde fixed tissues and the interval is similar for all subjects. Occupational and residential histories were collected blindly. The concentration of mineral particles is similar in subjects with and without occupational exposure, which gives an indication of the absence of bias.

Limited evidence is available on the concentration of $\mathrm{ABs}$ and $\mathrm{AFs}$ in environmentally exposed populations. Published results show large variability, because of differences in case mix, presence of occupational exposure, intensity of exposure, and analytical methods. Moreover, in some instances environmental exposure is defined in only very general terms, such as "urban" and "rural", whereas in the present study it is clearly defined in relation to a source of occupational and environmental asbestos exposure.

The present study shows consistent (not always significant) variations in the concentration of $\mathrm{AFs}$ and $\mathrm{ABs}$ in relation to both occupational asbestos exposure and residence in Casale Monferrato.

The concentration of $1000 \mathrm{AB} / \mathrm{gdw}$ or higher can be taken as a cut off point as it is considered indicative of occupational exposure to asbestos. ${ }^{19-23}$ This concentration was exceeded by eight out of 10 subjects with occupational exposure (six of seven persons employed in the asbestos cement factory), by five out of 18 of those non-occupationally exposed but living in Casale and by one of 13 of those non-occupationally exposed and never living in Casale. Mollo et $a l^{8425}$ and Andrion et $a l^{9}$ in consecutive studies on unselected necropsy samples in Torino found that the proportion of subjects without occupational exposure and presenting over $1000 \mathrm{AB} / \mathrm{gdw}$ was in the range $0 \%$ to $14 \%$. Roggli ${ }^{26}$ included in a review three studies on $\mathrm{AB}$ concentration in "control" populations, with average values in the range $20-280 \mathrm{AB} / \mathrm{gdw}$.

Case and Sebastien ${ }^{27}$ showed a gradient in $\mathrm{AF}$ and $\mathrm{AB}$ concentration between controls and environmentally exposed subjects living in the asbestos mining areas of Quebec. There was a median concentration of $480 \mathrm{AB} / \mathrm{gdw}$ in Asbestos and $1880 \mathrm{AB} / \mathrm{gdw}$ in Thetford whereas controls presented $80 \mathrm{AB} / \mathrm{gdw}$ and subjects occupationally exposed $35000 \mathrm{AB} /$ gdw. Corresponding figures for total AFs were $0.57 \times 10^{6}, 1.16 \times 10^{6}, 0.26 \times 10^{6}$, and $24.6 \times 10^{6}$ / gdw. Monsò et al ${ }^{28}$ found $\mathrm{ABs}$ in nine out of 18 non-occupationally exposed subjects living in Barcelona (range 0 to $430 \mathrm{AB} / \mathrm{gdw}$ ). Dufresne et $a l^{29}$ measured $\mathrm{ABs}$ and $\mathrm{AFs}$ in the lung of residents in Asbestos never occupationaly exposed and dying from diseases not related to asbestos: the average concentrations were 192 $\mathrm{AB} / \mathrm{gdw}$ and $208 \times 10^{6} \mathrm{AF} / \mathrm{gdw}$. Yamada et a ${ }^{30}$ found in 108 Japanese women a significantly higher concentration of ABs and AFs among urban than rural dwellers, measured by optical microscopy. 
Several studies have been conducted to use $\mathrm{AF}$ burden measured by electron microscopy for estimating occupational and environmental exposure, nevertheless the variation between laboratories is still large and makes the comparison of results from different laboratories uncertain. ${ }^{31}$ Roggli ${ }^{26}$ reviewed the published studies on $\mathrm{AF}$ burden in subjects not affected by asbestos related diseases: average concentrations ranged between $0.034 \times 10^{6}$ and $11.2 \times 10^{6}$ fibres/gdw. Churg, ${ }^{32}$ on the basis of these uncertainties, recommended the use of internal reference values in each laboratory but until now there is no generally accepted value of fibre concentration to distinguish between fibre burden of the "normal" population and of occupationally exposed subjects. ${ }^{33}$ Present results are therefore compared with findings in the ISS laboratory, obtained in the city of Rome among subjects without evidence of occupational exposure to asbestos. ${ }^{15}$ Asbestos fibres were found in the lungs in nine of 18 subjects who ever lived in Casale Monferrato $v 14$ of 85 in Rome $(p<0.003)$. In addition, chrysotile fibres were present in 33\% of positive subjects (those with AFs) in Casale and in 68\% in Rome and corresponding values for amphiboles were $89 \%$ and $32 \%$. Fibre concentration in Rome ranged between 0.2 and $3 \times 10^{6} \mathrm{AF} / \mathrm{gdw}$. The range of fibre length was $1-50 \mu \mathrm{m}$ (mean $13.6 \mu \mathrm{m}$ ) in Casale and 1-8 $\mu \mathrm{m}$ (mean $3 \mu \mathrm{m}$ ) in Rome. Diameters were similar in the two studies. These differences are consistent with the likely substantial differences in the main source and the intensity of airborne asbestos exposure in the two cities. In Casale asbestos exposure is related mostly to asbestos cement production and to the use of asbestos cement products whereas in Rome it is related to vehicle circulation and only to a lesser extent to asbestos cement used in the building industry.

Concentration of chrysotile fibres in this study was low, even among occupationally exposed subjects. This finding corresponds with the results of studies on workers exposed to mixed fibres, ${ }^{17}{ }^{18}$ on chrysotile only, ${ }^{34}$ and with a lower biopersistency of chrysotile compared with amphibole fibres.

Out of 31 subjects not engaged in occupations at probable asbestos exposure, two had histological signs of asbestosis and nine of SAL, which is considered likely indicative of asbestos exposure. ${ }^{13}$ No suggestion of occupational or domestic exposure was found for the two women with asbestosis. To our knowledge, this is a new finding, which indicates high levels of environmental asbestos exposure in the past. Asbestosis in relation to environmental exposure has been reported in Turkey and attributed to high environmental levels of tremolite..$^{35}$ The two cases of non-occupational asbestosis had $800 \mathrm{AB} / \mathrm{gdw}$, which is the average for women living in Casale and not occupationally exposed. In the interpretation of this value we must take into consideration that individual susceptibility plays a part in both the pathogenesis of asbestosis ${ }^{36}$ and the production of ABs. ${ }^{37}$ Dodson et $a l^{37}$ described lung asbestosis even without finding $\mathrm{ABs}$ in digested lungs. Moreover, chrysotile, which is fibrogenic but induces low production of $\mathrm{ABs},{ }^{38}$ accounts for $50 \%-85 \%$ of airborne $\mathrm{AFs}$, (longer than $5 \mu \mathrm{m}$ ) in the general environment of Casale.

\section{Conclusion}

We found two cases of histological asbestosis, a high prevalence of SAL, and a high concentration of ABs among people with no occupational exposure who lived in Casale Monferrato, which confirms the high prevalence of environmental asbestos exposure that was experienced in the area in relation to asbestos cement production.

The study was conducted thanks to grants from Associazione Italiana per la Ricerca sul Cancro (AIRC), Piemonte Region and EEC Europe Against Cancer Programme. We are indebted to Professor B Terracini for his comments, to Dr Paola Budel who helped in data collection, and to Mrs Monica Garbero and Mrs Rita Giacometti who edited the text.

1 Magnani C, Terracini B, Ivaldi C, et al. Mortalità per tumori e altre cause tra i lavoratori del cemento-amianto a Casale Monferrato. Uno studio di coorte storico. Med Lav 1996;87:133-46.

2 Magnani C, Terracini B, Ivaldi C, et al. A cohort study on mortality among wives of workers in the asbestos cement
industry in Casale Monferrato, Italy. $\mathrm{Br} \mathcal{F}$ Ind Med 1993;50:779-84.

3 Magnani C, Terracini B, Ivaldi C, et al. Pleural malignant mesothelioma and non-occupational exposure to asbestos

in Casale Monferrato. Occup Environ Med 1995;52:362-7. concentrations in an urban area near an asbestos-cement concentrations in an urban area near
plant. IARC Sci Publ 1989;90:336-46.

5 Chiappino G, Sebastien P, Todaro A. L'inquinamento Chiappino G, Sebastien P, Todaro A. L'inquinamento atmosferico da amianto nell'ambiente urbano: Milano, Med Lav 1991;82:424-38.

6 Chiappino G, Todaro A, Blanchard O. L'inquinamento atmosferico da amianto nell'ambiente urbano: Roma, Orbassano e località di controllo (11 parte). Med Lav 1993;84:187-92.

7 Paoletti L, Falchi M, Viviano G, et al. Features of airborne breathable particulate in a remote rural and in an urban area. Water Air and Soil Pollution 1989;43:85-94.

8 Mollo F, Andrion A, Bellis D, et al. Screening of autopsy populations for previous occupational exposure to asbestos. Arch Environ Health 1987;42:44-50.

9 Andrion A, Bellis D, Bertoldo E, et al. Coated and uncoated lung mineral fibres in subjects with and without pleural plaques at autopsy. Pathol Res Pract 1984;178:611-6.

10 Morgan A, Holmes A. Concentrations and dimensions of Morgan A, Holmes A. Concentrations and dimensions of
coated and uncoated asbestos fibres in the human lung. $\mathrm{Br}$ f Ind Med 1980;37:25-32.

11 Craighead JE, Abraham JL, Churg A, et al. The pathology of Craighead JE, Abraham JL, Churg A, et al. The pathology of
asbestos-associated diseases of the lungs and pleural cavities: diagnostic criteria and proposed grading schema. Arch Pathol Lab Med 1982;106:544-95.

12 Wright JL, Churg A. Morphology of small-airway lesions in patients with asbestos exposure. Hum Pathol 1984;15:6874.

13 Bellis D, Andrion A, Delsedime L, et al. Minimal pathologic changes of the lung and asbestos exposure. Hum Pathol 1989;20:102-6

14 Falchi M, Paoletti L. Metodiche e strumenti per l'analisi delle fibre di amianto in organi e tessuti umani. Ann Ist Super Sanita 1994;30:139-49.

15 Paoletti L, Falchi M, Batisti D, et al. Mineral lung burden of an urban population. Atmospheric Environment 1991;25: $381-5$.

16 Zar JH. Biostatistical analysis, 2nd edition. Englewood Cliffs: Prentice-Hall, 1984:138-45, 176-9.

17 Churg A, Wright J. Persistence of natural mineral fibres in human lungs: an overview. Environ Health Perspect 1994; 102:229-33.

18 Langer AM, Nolan RP. Chrysotile biopersistence in the lungs of persons in the general population and exposed workers. Environ Health Perspect 1994;102:235-9.

19 Gibbs GW. Biological indicators and their clinical significance in persons exposed to mineral fibres: report of a workshop held in Japan, 24-25 November 1991. Br f Ind Med 1993;50:412-7.

20 Churg A, Warnock ML. Correlation of quantitative asbestos body counts and occupation in urban patients. Arch Pathol Lab Med 1977;101:629-34.

21 Dodson RF, Williams MG, Corn CJ, et al. A comparison of asbestos burden in non-urban patients with and without lung cancer. Cytobios 1988;56:7-15.

22 Kishimoto T, Okada K. The relationship between lung cancer and asbestos exposure. Chest 1988;94:486-90.

23 Arenas-Huertero FJ, Salazar-Flores M, Osornio-Vargas AR Ferruginous bodies as markers of environmental exposure Ferruginous bodies as markers of environmental exposure
to inorganic particles: experience with 270 autopsy cases in Mexico. Environ Res 1994;64:10-17. 
24 Mollo F, Pira E, Piolatto G, et al. Lung adenocarcinoma and indicators of asbestos exposure. Int $\mathcal{F}$ Cancer 1995;60:289 indicat

25 Mollo F, Andrion A, Bellis D, et al. Optical determination of coated and uncoated mineral fibres in lungs of subjects without professional exposure. Applied Pathology 1983;1 276-82.

26 Roggli VL. Human disease consequences of fiber exposures: a review of human lung pathology and fiber burden data Environ Health Perspect 1990;88:295-303.

27 Case BW, Sebastien P. Fibre levels in lung and correlation with air samples. In: Bignon J, Peto J, Saracci R, eds. Nonoccupational exposure to mineral fibres. Lyon: IARC, 1989: 207-18. (IARC Sci Publ No 90.)

28 Monsò E, Texidò A, Lopez $\mathrm{D}$, et al. Asbestos bodies in normal lung of western Mediterranean populations with no occupational exposure to inorganic dust. Arch Environ Health 1995;50:305-11

29 Dufresne A, Bégin R, Massé S, et al. Retention of asbestos fibres in lungs of workers with asbestosis, asbestosis and lung cancer and mesothelioma in Asbestos township. Occup lung cancer and mesotheliom in

30 Yamada $\mathrm{H}$, Hashimoto $\mathrm{H}$, Akiyama $\mathrm{M}$, et al. Talc and amosite/crocidolite preferentially deposited in the lungs of nonoccupational female lung cancer cases in urban areas of Japan. Environ Health Perspect 1997;105:504-8.
31 Glyseth B, Churg A, Davis JMG, et al. Analysis of asbestos fibers and asbestos bodies in tissue sample from human lung (an international laboratory trial). Scand $\mathcal{F}$ Work Environ Health 1985;11:107-10.

32 Churg A. Analysis of lung asbestos content. Br f Ind Med 1991;48:649-52.

33 Friedrichs $\mathrm{KH}$, Brockmann M, Fisher M, et al. Electron microscopy analysis of mineral fibers in human lung tissue. Am F Ind Med 1992;22:49.

34 Churg A, Wright JL, Vedal S. Fiber burden and patterns of asbestos-related diseases in chrysotile miners and millers. am Rev Respir Dis 1993;148:25-31.

35 De Vuyst P, Dumortier P, Jacobovitz D, et al. Environmental asbestosis complicated by lung cancer. Chest 1994;105: 1593-5.

36 Becklake MR. Asbestos-related diseases of the lung and pleura. Current clinical issues. Am Rev Respir Dis 1982;126:187-94.

37 Dodson RF, Williams MG Jr, O'Sullivan MF, et al. Comparison of ferruginous body and uncoated fiber content in lungs of former asbestos workers. Am Rev Resir Dis, 1985;132:143-7.

38 Churg A, Wright J, Wiggs B, et al. Mineralogic parameters related to amosite asbestos-induced fibrosis in humans. Am Rev Respir Dis 1990;142:1331-6.

\section{Rejected manuscripts}

From February 1994, authors whose submitted articles are rejected will be advised of the decision and one copy of the article, together with any reviewer's comments, will be returned to them. The fournal will destroy remaining copies of the article but correspondence and reviewers' comments will be kept. 